\title{
Architecture of Atwood Machine Props with Sensor-based Passive Infrared
}

\author{
Delia Achadina Putri ${ }^{1}$ and Dandan Luhur Saraswati ${ }^{2}$ \\ ${ }^{1,2}$ Pendidikan Fisika Universitas Indraprasta PGRI, Indonesia \\ J1. Raya Tengah No.80 Kel. Gedong, Kec. Pasar Rebo, Jakarta Timur \\ Email: deliachadina@gmail.com
}

\begin{abstract}
The aim of this research is to develop Atwood machine propswith sensor-based PIR (Passive Infrared) to determine the acceleration value of earth gravity. This type of research is an experiment conducted in the physics laboratory of Universitas Indraprasta PGRI. Atwood machine was developed by using PIR (Passive Infrared) sensors to detect the movement of the objects used. Based on the trialof the result of the data analysis experiment tool, the acceleration of gravity was obtained $(9.87 \pm 0.08) \mathrm{m} / \mathrm{s}^{2}$. Whereas the value of acceleration of gravity in the literature is $9,80665 \mathrm{~m} / \mathrm{s}^{2}$. The obtained results shows that the acceleration of gravity obtained in this research is not much different from the acceleration value of gravity found in the literature so that Atwood machine tool that is developed by using PIR sensor is recommended to be one alternative tool in determining the acceleration of earth gravity.
\end{abstract}

Key words: Acceleration of Gravity, Atwood machine, PIR (Passive Infrared) sensors

\section{Introduction}

Physics is not merely a theory lesson where its benefits cannot be perceived by society. Physics is one of the natural sciences which became the basis of a wide range of technologies in the world [I]. Physics study about natural phenomena or subject in the scope of space and time, so that the implementation of physics can be used to study how this natural phenomenon occurs [2]. In physics various motion of objects started from the motion of marbles, motion of planet rotation, motion of rocket, or even the motion of an apple falling from the tree are studied in the branch of physics called mechanics. In general mechanics is divided in two subjects, called the dynamics and kinematics. Dynamics study about motion of objects and its causes and kinematics study about motion of objects only without necessarily know the causes [3].

The Atwood machine is a tool that can be used to analyze the mechanisms used to measure acceleration. Typically, a teacher demonstrating the study of gravity only to prove the existence of gravity acceleration, for example by removing an object from a certain height, but students have never directly done the experiment to find out how to determine the acceleration value of gravity that they have been reading through books. The object will fall with an acceleration caused by the gravitational forces of the Earth or Earth's gravity. This Earth's gravity causes an object falling from a certain height with an acceleration known as the acceleration of Earth's gravity.

The acceleration of Earth's gravity is influenced by the distance of an object from the Earth's center and the density of Earth's composition in that coordinate [4]. The acceleration of Earth's gravity symbolized by ' $\mathrm{g}$ indicates the average acceleration produced by gravitational field on the Earth surface with unit $\mathrm{m} / \mathrm{s}^{2}$ [5]. With the advance of science, technology and also latest innovation, it provide an opportunity for researchers to create Atwood machine props. Nowadays, Atwood's machine is used with purposes to demonstrate uniformly accelerated motion with smaller acceleration than the gravitational acceleration $g[6]$.

The Atwood's machine is a device where two masses hang from the ends of string passing over a pulley that can freely rotate on its horizontal axis [7]. The Atwood machine is an experimental tool used to observe uninform mechanics' law of motion. This tool began to be developed around the eighteenth century to measure the acceleration of gravity. The props used to describe the relationship between stress, potential energy and kinetic energy using two ballast (different mass) which are $\mathrm{m}_{\mathrm{I}}(\mathrm{M}+\mathrm{m})$ and $\mathrm{m}_{2}(\mathrm{M})$ connected by a string on a pulley. Objects with larger mass $(\mathrm{mI})$ is higher in position than the lighter mass $\left(\mathrm{m}_{2}\right)$. Thus, an object with mass $\mathrm{m}_{2}$ will move down because of the effect of gravitational acceleration and pull $\mathrm{mi}$ because of the connected rope in the pulley. 
Simply put, this tool is composed of a rope connected to a pulley, which at the end of the rope is hooked with mass of loadsmi and $\mathrm{m}_{2}$. If the mass of the object $\mathrm{m}_{\mathrm{I}}$ and mare equal $\left(\mathrm{m}_{1}=\mathrm{m}_{2}\right)$, then both will be silent. However, if the mass of the object $\mathrm{m}_{2}$ is greater than the mass of the object $\mathrm{m}_{\mathrm{I}}$, then the mass $\mathrm{m}_{\mathrm{I}}$ will be pulled by the mass.

In this research, the PIR sensor used is HC-SR50I type. Needs of HC-SR50I sensor input according to its datasheet is $4.5-20 \mathrm{~V} \mathrm{DC}$ with maximum current $50 \mathrm{uA}$. The ability to detect the sensor from 3-7 meters with delay between $5-200$ seconds. The angle range is $140^{\circ}$ [8].

\section{Literature Review}

Today, it is common that many experimental physics programs include Atwood machines and variable masses to introduce more complex concepts in physics. To study the mass dynamics that make up the Atwood variable machine, the lab usually uses intelligent pulleys [9].

In thisAtwood machine contain elements of translational Motion that is uninform linear motion(GLB) and accelerated linear motion (GLBB). According to Marthen Kanginan, uninform linear motionis a rectilinear motion of an object, where in this motion its velocity fixed or no acceleration, so the distance traveled is speed times time [IO]. While the accelerated linear motion is rectilinear motion of an object, where the velocity is changing [II]. Not only the uninform linear motion or accelerated linear motion but the working principles of the pulley is also appl. A pulley is a wheel with a rope around and used to ease the work of people [12].

The acceleration of earth's gravity is the acceleration experienced by objects that fall freely from a certain height toward the Earth's surface. Based on the literature, the earth's gravity acceleration value is equal to $9,80665 \mathrm{~m} / \mathrm{s}^{2}[\mathrm{I} 3]$. The direction of gravitational acceleration is toward the center of the Earth or perpendicular to the surface of the ground. The magnitude of gravitational acceleration in several different places may not be exactly equal to 9.80665 $\mathrm{m} / \mathrm{s}^{2}$. This is due to the difference in mass density and distance of a place from the center of the Earth[I4].

The sensor is the equipment used to change a physical quantity to electricity quantity so it can be analyzed with specific electrical network[I5].Passive Infrared sensor is a low cost, low power and reliable sensor [I6]. PIRbased system saves power consumption and memory space [I7]. IR filter contained in the PIR sensor is capable of filtering the wavelength of passive infrared light between 8 to I 4 micrometers. This infrared ray is then captured by the pyro-electric sensor which is the core of the PIR sensor. The pyro-electric sensor consists of gallium nitride, cesium nitrate and litium tantalite which produces an electric current [8].However, unlike most of others infrared where they consist of LED and fototransistor, PIR does not emit anything as IR LEDs. In accordance with the name 'passive', this sensor only responds energy from the passive infrared beams which are owned by any objects detected by it[I8]. PIR sensor has two sensing elements connected to the inputwith the order as shown in the following figure [I9].
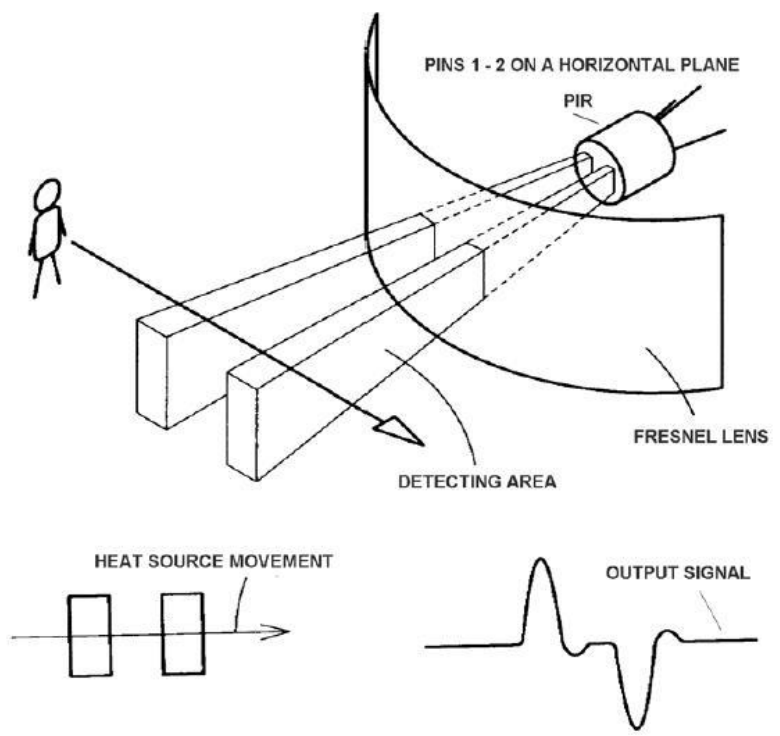

Figure I. PIR Sensor Wave Range Direction

\section{Research Methods/Experiment}

I. Tools and materials: Atwood machine consist of:

a. The pole with a pullet at the top

b. A hanging rope with a negligible mass

c. Two load of mi (just above the sensor hole of timer I) and $\mathrm{m}_{2}$ (located on the stopper) cylindrical with a sharp point underside

d. Stopper to hold $\mathrm{m}_{2}$

e. Sensor I (at point A) used to turn on stopwatch I. Sensor 2 (at point B) with double function that are turn off stopwatch $I$ and simultaneously turn on stopwatch 2. Sensor 3 (at point C) turnoff stopwatch 2 .

f. The Stopwatch box, which contains stopwatch I to record time from point $A$ to point $B$. Stopwatch 2 to record time from point B to point C. 
2. Tool Design:

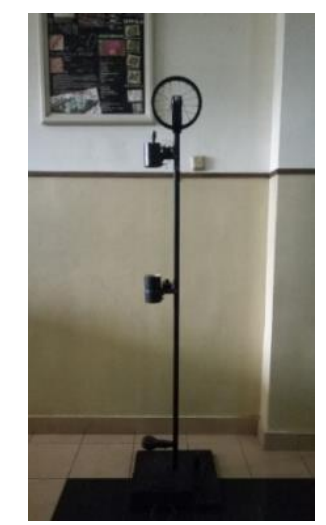

Figure 2. Atwood Tool Design

3. Step Tes Tool :

a. Prepare the atwood machine device in a flat ground.

b. Set $\mathrm{mi}$ right above the timer sensor $\mathrm{I}$ and located in thecenterhole of the sensor and one load again on stopper $\left(\mathrm{m}_{2}\right)$.

c. Turn on all stopwatch and reset to zero (0)

d. The size of the components required for the calculation of the Atwood machine is as follows:

Table I. Table of Component Amount

\begin{tabular}{cc}
\hline Quantity & Units $(\mathrm{kg}) \mathrm{z}$ \\
\hline Mass of the load & 0,07 \\
Mass of the pulley & 0,4
\end{tabular}

e. Press the stopper so mass $m_{2}$ and $m_{1}$ apart from the andmoving down pass the hole sensor timer I to turn on the stopwatch I, then pass hole sensor timer 2 with double function that is turning off stopwatch I and simultaneously turn on the stopwatch 2, and the last pass through the sensor hole 3 to turn off the stopwatch 2 .

f. Observe and record how much time is shown on stopwatch I (time from point $A$ to $B\left(t_{A B}\right)$ ) and stopwatch 2 (time from point $\mathrm{B}$ to $\mathrm{C}$ $(\mathrm{tBC}))$.

g. Calculate the acceleration value of gravity by using the formula:

$g=\frac{(2 \bar{M}+\bar{m}+\overline{m p}) \cdot \bar{a}}{\bar{m}}$

\section{Research Results and Discussion}

In this research we get experiment data that is:

Table II. Experiment Data

\begin{tabular}{cccccc}
\hline No & $\begin{array}{c}\text { Load } \\
\text { Mass }[\mathrm{M}] \\
(\mathrm{kg})\end{array}$ & $\begin{array}{c}\text { Mass } \\
\text { of } \\
\text { Ballast } \\
{[\mathrm{m}]}\end{array}$ & $\begin{array}{c}\text { Time A-B } \\
{\left[\mathrm{t}_{\mathrm{AB}}\right](\mathrm{s})}\end{array}$ & $\begin{array}{c}\text { Time } \\
\mathrm{B}-\mathrm{C} \\
{[\mathrm{tBC}]}\end{array}$ & $\begin{array}{c}\text { Acceleration } \\
{[\mathrm{a}]\left(\mathrm{m} / \mathrm{s}^{2}\right)}\end{array}$ \\
& & & $\mathrm{s})$ & \\
\hline $\mathrm{I}$ & 0,070 & 0,010 & 2,75 & $\mathrm{I}, 34$ & 0165530 \\
2 & 0,072 & $0,01 \mathrm{I}$ & 2,70 & $\mathrm{I}, 24$ & 0,180998 \\
3 & 0,070 & $0,01 \mathrm{I}$ & 2,50 & $\mathrm{I}, 30$ & 0,182820 \\
4 & 0,069 & 0,012 & 2,45 & 1,35 & 0,176045 \\
5 & $0,07 \mathrm{I}$ & 0,010 & 2,68 & 1,26 & 0,179207 \\
\hline
\end{tabular}

After the data were analyzed and the acceleration value of earth gravity was calculated by using the equation (I), so the earth gravity acceleration value in this study was $(9,87 \pm 0,08) \mathrm{m} / \mathrm{s}^{2}$. These results are better than research conducted by Syahrul, et al, who get the acceleration value of earth gravity that is 9,619 $\mathrm{m} / \mathrm{s}^{2}[20]$. The value obtained in this study is not much different from the literature that underlie this research which is $9,80665 \mathrm{~m} / \mathrm{s}^{2}$.

\section{CONCLUSION}

I. A simple atwood machine can be used to measure the magnitude of earth's gravitional acceleration

2. The acceleration value of gravity obtained in this research is equal to $(9,87 \pm 0,08) \mathrm{m} / \mathrm{s}^{2}$. The value obtained in this study is not much different from the literature that underlie this research which is $9,80665 \mathrm{~m} / \mathrm{s}^{2}$.

\section{Acknowledgement}

Researchers say thanks to Oki Mustava and Dr. Dwi Sulisworo, M.T who has been a reviewers of the journal that has researchers create and thanks to the Indonesian Review of Physics that can publish our journal as well as the physics laboratory of the UniversitasIndraprasta PGRI which has become our research place.

\section{Literature}

[I] Firman Nugraha, et al, Eksperimen Pesawat Atwood Berbasis Pengolahan Aplikasi Tracker untuk Mengamati Fenomena Gerak Lurus Beraturan dan Gerak Lurus Berubah Beraturan pada Pembelajaran Fisika SMA (Atwood Aircraft Experiments Based on Tracker Application Processing to Observe the phenomenon of Regular Straight Motion and Regularly Changed Straight Motion on High School Physics Learning), Prosiding Seminar Nasional Fisika SNF 20I7, vol. 6, 2017, p-ISSN: 2339-0654

[2] Hendrik Tri Wicaksoni, Eko Setyadi Kurniawan and H. Arif Maftukhin, Pengembangan Alat Peraga Resonator sebagai Alternatif Media Pembelajaran pada Materi Gelombang Bunyi (Development of Resonator Teaching Tools as Alternative 
Learning Media in I2th Grade Sound Wave Material in High School), Radiasi, vol. 3, no. 2, 2013

[3] John Adler and Dida Nurdiansyah, Sistem Komputasi Gerak Lurus Beraturan (GLB) pada Pesawat Atwood Menggunakan Mikrokontroler (Accelerated Uniform Motion Computing System on Atwood Plane Using a Microcontroller), Unikom, 2017

[4] Handy Indra Regain Mosey and Benny Max Lumi, Penentuan Percepatan Gravitasi Lokal di Universitas SAM Ratulangi Manado Berdasarkan Teori Getaran Harmonik (Determination of Local Gravity Acceleration at SAM Ratulangi University Manado Based on Theory of Harmonic Vibration)

[5] Eka Putri Rinanthy, Hufri and Zulhendri Kamus, Pembuatan Alat Penentuan Percepatan Gravitasi Bumi Menggunakan Metode Pendulum Berbasis Sensor Cahaya LDR (Making a Determination Tool for Earth Gravity Acceleration Using the Pendulum Method Based on LDR Light Sensors), Pillar of Physics, vol. 8, 2016

[6] Mariusz Tarnopolski, On Atwood's Machine with a Nonzero Mass String, American Association of Physics Teacher, vol 53, 2015, doi: I0.1119/1.4933154

[7] Barbara Pecori, Giacomo Torzo and Andrea Sconza, Harmonic and an-harmonic oscillations investigated by using a microcomputer-based Atwood's machine, American Association of Physics Teacher, vol 67, 1999, doi: I0.1119/I.1923

[8] Deni Kurnia and Rizky Fitri Hidayatullah, Integrasi Teknik Pendeteksian Obyek Menggunakan Sensor PIR dengan Kontrol Pergerakan Sliding Camera pada Sistem Kemanan Bengkel (Integration of Object Detection Techniques Using a PIR Sensor with Movement Control of the Sliding Camera on the Workshop Security System), Jurnal SIMETRIS, vol. 7, no. 2, 2016, ISSN 2252-4983

[9] Deny Lopez, IsidoraCaprile, Fernando Corvacho and Orfa Reyes, Study of a variable mass Atwood's machine using a smarthphone, The Physics Teacher, vol. 56, no. 3, 2018, p. I82-183

[10] Marthen Kanginan, Fisika SMA untuk Kelas X (High School Physics for Class I0), Erlangga, 2006.

[II] Wasino, Arif Maftukhin and Eko Setyadi Kurniawan, Pengembangan Pesawat Atwood Berbasis Sensor LDR (Light Dependent Resistor) sebagai alat peraga GLB dan GLBB (Atwood Airplane Development Based on LDR Sensor (Light Dependent Resistor) as Uniform Rectilinear Motion and Accelerated Uniform Motion props), Radiasi, vol. 3, no. 2, 2013.
[I2] Imas Ratna Ermawaty, Y. Soenarto and Felicianda, Analisis Double Integral pada Momen Inersia dalam Pesawat Atwood Menggunakan Katrol dengan Penambahan Massa Beban (Integral Double Analysis at the Moment of Inertia in the Atwood Plane Using Pulleys with Load Mass Addition), Prosiding Kolokium Doktor dan Seminar Hasil Penelitian, 2017.

[I3] Ganijanti Aby Sarojo, Edisi 5: Mekanika (Mechanics), Salemba Teknika, 2016.

[14] Disah Nur Afifah, Dewi Yulianawati, Nina Agustina, Ratu Dewi Sri Lestari and Muhamad Gina Nugraha, Metode Sederhana Menentukan Percepatan Gravitasi Bumi Menggunakan Aplikasi Tracker pada Gerak Parabola sebagai Media dalam Pembelajaran Fisika SMA (Simple Method to Determine Earth Gravity Acceleration Using Tracker Application on Parabolic Motion as a Media in High School Physics Learning), Prosiding Seminar Nasional Inovasi dan Pembelajaran Sains, Bandung, Juni 2015, ISBN: 978-196558-0.

[15] Zuly Budiarso and Eddy Nurraharjo, Sistem Monitoring Tingkat Ketinggian Air Bendungan Berbasis Mikrokontroler (Microcontroller Based Dam Water Level Monitoring System), Jurnal Dinamika Informatika, vol 3, no. I, 20 I I

[16] Pema Chodon, et al, Passive Infrard (PIR) Sensor Based Security System, International Journal of Electrical, Electronic and Computer System, vol. I4, issue. 2, 2013

[17] Shafiqul Abidin and Manu Ahuja, Infra Red Radiation Detection using Paassive Infrared Sensor, International Journal of Computer Applications, vol. I52, no. 5, 2016

[18] Jati Lestari and Grace Gata, Webcam Monitoring Ruangan Menggunakan Sensor Gerak PIR (Passive Infra Red) (Webcam Monitoring Room Using PIR (Passive Infra Red) Motion Sensor), BIT, vol. 8, no. 2, 20II, ISSN: I893-9I66

[19] Berri Parima dan Rozeff Pramana, Perancangan Sistem Keamanan Rumah Menggunakan Sensor Passive Infra Red Berbasis Mikrokontroler (Home Security System Design Using Microcontroller Based Passive Red Sensor), Teknik Elektro, 2013

[20] Syahrul, Jhon Adler and Andriana., Pengukur Percepatan Gravitasi Menggunakan Gerak Harmonik Sederhana Metode Bandul (Measuring Gravity Acceleration Using Simple Harmonic Motion of the Pendulum Method), Jurnal Teknik Komputer Unikom, vol. 2, no. 2, 2013, https://repository.unikom.ac.id/30330/I /2.syahrulpengukur-percepatan-gravitasi.pdf diakses pada tanggal 28 Mei 2018 